\title{
Microplastic Contamination in Protected Areas of the Gulf of Venice
}

\author{
Michele Mistri • Marco Scoponi • Andrea A. Sfriso • Cristina Munari • \\ Marta Curiotto · Adriano Sfriso $\cdot$ Martina Orlando-Bonaca $\cdot$ Lovrenc Lipej
}

Received: 13 May 2021 / Accepted: 18 August 2021 / Published online: 7 September 2021

(C) The Author(s) 2021

\begin{abstract}
We investigated the concentration and composition of plastics in 7 Special Areas of Conservation (SACs) from the Gulf of Venice (northern Adriatic Sea). A total of 42 sediment samples were analyzed from 21 sites from 2017 to 2018. All sites except one were found to be polluted by plastics, with density ranging between 2250 and 28.4 items $\mathrm{kg}^{-1}$. Microplastics ranged from 100 to $61.6 \%$ of the collected plastics. Fragments were more represented than filaments. The greatest plastic concentrations were generally recorded in western SACs. Identification
\end{abstract}

M. Mistri $(\bowtie) \cdot$ A. A. Sfriso · C. Munari - M. Curiotto Department of Chemical, Pharmaceutical and Agricultural Sciences, University of Ferrara, Via Fossato di Mortara 17, 44121 Ferrara, Italy

e-mail: michele.mistri@unife.it

M. Scoponi

ISOF-CNR, Department of Chemical, Pharmaceutical and Agricultural Sciences, University of Ferrara, Via Luigi Borsari 46, 44121 Ferrara, Italy

M. Scoponi

Advanced Polymer Materials, Via G. Saragat 9, 44122 Ferrara, Italy

A. Sfriso

Department of Environmental Sciences, Informatics and Statistics, University Ca' Foscari, Via Torino 155, 30127 Mestre, Venice, Italy

M. Orlando-Bonaca $\cdot$ L. Lipej

Marine Biology Station Piran, National Institute

of Biology, Fornače 41, 6630 Piran, Slovenia through FT-IR spectroscopy evidenced the presence of 8 polymer types: in western SACS, the majority were low-density polymers (PE, PP, PS, and TPU), while in eastern SACs they were high-density polymers (PET, nylon, and PVC). In addition to the role of large rivers (all on the western side of the Gulf) in conveying plastics into the sea, a possible role of the cyclonic water circulation of the northern Adriatic Sea on distribution and composition of plastics along the Gulf coasts is likely.

Keywords Microplastics - Special Areas of Conservation · Polymer composition $\cdot$ Gulf of Venice $\cdot$ FT-IR spectroscopy

\section{Introduction}

Plastic pollution is increasingly recognized as a major threat to marine biodiversity (Bergmann et al., 2015). In the last 50 years, world plastic production has increased from 1.7 to 348 million tons, with a proportional increase in the production of plastic waste (PlasticsEurope, 2018). Part of this waste is eventually discharged into the environment, a problem exacerbated by the common use and inappropriate disposal of throw-away "user" plastic products that ultimately reach the sea. Approximately 14 million tonnes of plastic litter is dumped in the oceans each year (Jambeck et al., 2015). An estimated $40 \%$ of that falls into the "single-use" category, which means it 
winds up in the ocean within the same year as it was produced (UNEP, 2018). When at sea, plastic litter degrades slowly through a combination of photo-oxidation and mechanical abrasion, resulting in the production of small fragments and microplastics. Microplastics are considered specifically in descriptor 10 of the Marine Strategy Framework Directive (MSFD, 2008/56/EC), i.e., "Trends in the amount, distribution and, where possible, composition of micro-particles (in particular micro-plastics)," and "The amount of litter and micro-litter ingested by marine animals is at a level that does not adversely affect the health of the species concerned." Indicators for the latter criterion should be developed in the current implementation cycle of MSFD.

The assessment of plastic and microplastic pollution at sea is relatively recent, and extensive areas of the ocean remain poorly explored. This is the case of the Mediterranean Sea (UNEP/MAP/MEDPOL, 2009), whose shores house around $10 \%$ of the global coastal population. Microplastic pollution in the Mediterranean is a problem whose extent has been only recently recognized (Gago et al., 2015). In their review, Cózar et al. (2015) reported that floating small plastic abundances in the Mediterranean Sea (from 22 to $1934 \mathrm{~g} \mathrm{~km}^{-2}$ ) were similar to those found in the Pacific Ocean gyres. Among Mediterranean regions, the Adriatic Sea is characterized by one of the greatest seafloor plastic pollutions (from171 \pm 36 to $47.87 \pm 23.38 \mathrm{~kg} \mathrm{~km}^{-2}$; Strafella et al., 2015; Pasquini et al., 2016; Mistri et al., 2017), and recent studies suggest that the northern Adriatic coast is vulnerable to plastic accumulation on the shores (Laglbauer et al., 2014; Munari et al., 2016, 2017a, b).

Protected areas (e.g., Sites of Community Importance, SCIs, and Special Areas of Conservation, SACs, under the Habitats Directive 92/43/CEE) are highly recommended tools for the conservation of marine habitats and species in the face of the impact of human activities (Lubchenco and Grorud-Colvert, 2015). Many activities are excluded in these areas, such as dumping of dredged materials, spilling of wastewaters, and mining for oil and gas. However, these areas, despite the standards of protection to which they are subjected, can be equally subject to accumulation of waste and pollutants coming from elsewhere. In the Gulf of Venice (the northern part of the Adriatic Sea, limited by an imaginary diagonal line between the Sacca di Goro on the west and Rt
Kamenjak on the east), there is a number of transition protected areas (SACs, under the Habitats Directive) both on eastern and western side. The Gulf of Venice is heavily impacted by many human activities: intense marine traffic, fisheries, coastal and offshore aquaculture, and pollutants and litter discharge through many rivers (dominated by the Po).

Protected areas are also impacted by the arrival of pollutants on their seafloor, especially by microplastics (Vianello et al., 2013). Plastic pollution is particularly problematic in coastal ecosystems subject to riverine inputs (e.g., lagoons, estuaries, and coastal wetlands) that provide essential habitat for many commercially important species, such as fish and shellfish. Ingestion of plastic by organisms may pose a variety of risks including oxidative stress, cell damage, inflammation, and leaching of chemical contaminants (Vethaak \& Leslie, 2016). For these reasons, it is important to document the occurrence of microplastics in coastal systems of the northern Adriatic Sea, an area reported as one of the most plastic-polluted seas of the world (Pasquini et al., 2016; Strafella et al., 2015).

To obtain a full picture of the microplastic pollution in protected transition systems of the Gulf of Venice, we conducted an extensive investigation of the abundance and composition of microplastics in the sediments of selected SACs from 2017 to 2018.

\section{Materials and Methods}

Figure 1 shows a map of the Gulf of Venice with the 7 considered SACs. These were as follows: IT4060005 "Sacca di Goro" (2 sites: GOR1 and GOR2), IT3270017 "Delta del Po: tratto terminale e delta veneto" (4 sites: MAR1, MAR2, CAL1, and CAL2), IT3250030 "Laguna medio-inferiore di Venezia" (2 sites: VE1 and VE2), IT3250031 "Laguna superiore di Venezia" (2 sites: VE3 and VE4), SI3000240 "Sečoveljske Soline in Estuarij Dragonje" (3 sites: JERKA1, JERKA2, JERKA3), SI3000238 "Strunjanske Soline s Stjužo" (3 sites: STJUZA1, STJUZA2, and STJUZA3), and SI3000252 "Škocjanski Zatok" (3 sites: SKOZA1, SKOZA2, and SKOZA3). Coordinates and characteristics of the sampling sites are reported in Table 1.

Surface sediment samples (about $2 \mathrm{~kg}$ ) were collected in duplicate at each sampling site. Sediment 


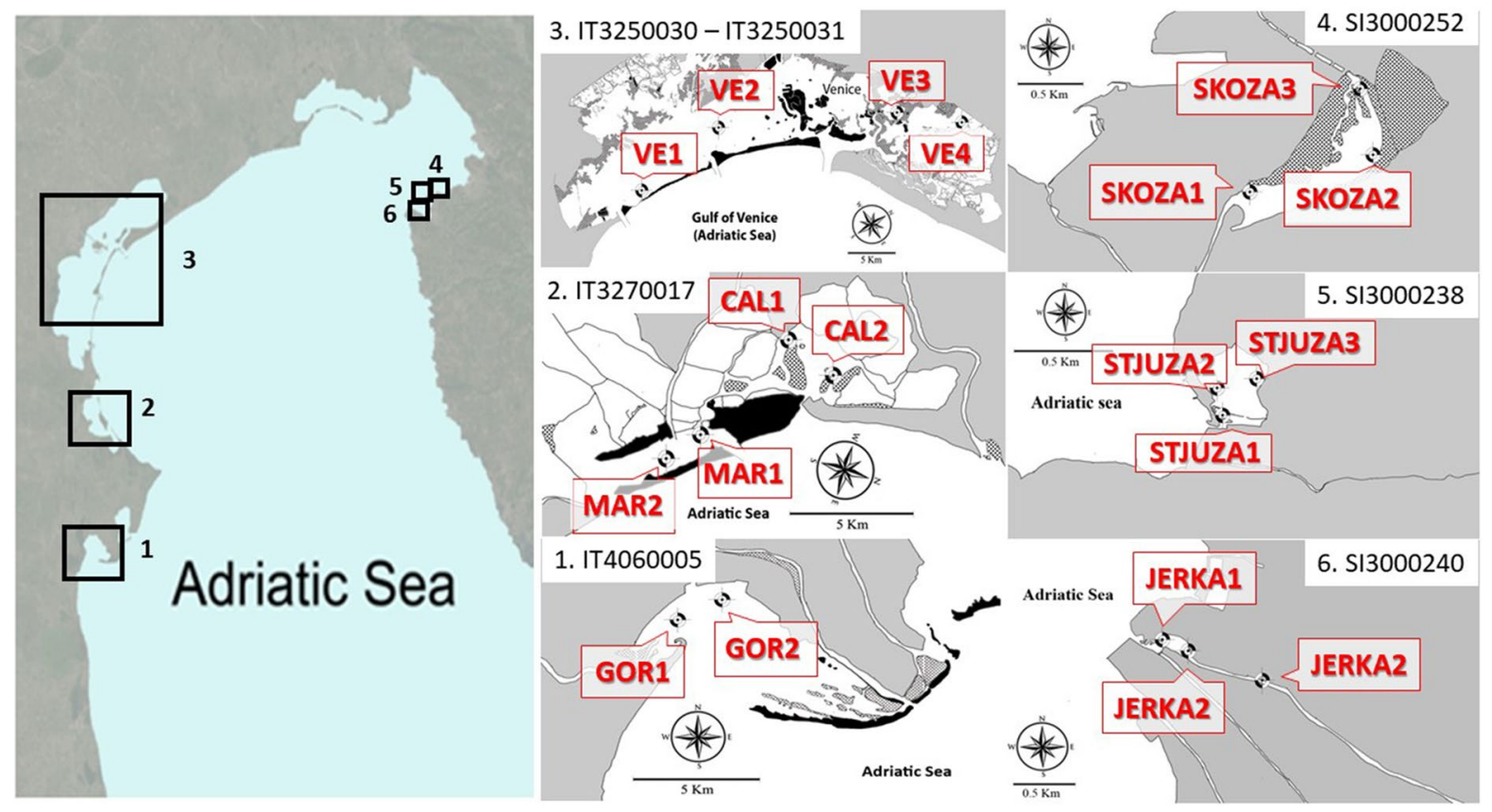

Fig. 1 Gulf of Venice: study site location

Table 1 Sampling site coordinates and characteristics

\begin{tabular}{|c|c|c|c|c|c|c|c|c|}
\hline SAC & Site & Lat & Long & $\begin{array}{l}\text { Depth } \\
\mathrm{m}\end{array}$ & $\begin{array}{l}\text { Sand } \\
\%\end{array}$ & $\begin{array}{l}\text { Silt } \\
\%\end{array}$ & $\begin{array}{l}\text { Clay } \\
\%\end{array}$ & Seagrass \\
\hline \multirow[t]{2}{*}{ IT4060005 } & GOR1 & $44^{\circ} 49.585^{\prime} \mathrm{N}$ & $12^{\circ} 16.602^{\prime} \mathrm{E}$ & 1.2 & 11.9 & 37.7 & 50.5 & NO \\
\hline & GOR2 & $44^{\circ} 50.155^{\prime} \mathrm{N}$ & $12^{\circ} 17.814^{\prime} \mathrm{E}$ & 0.8 & 11.2 & 32.9 & 55.9 & NO \\
\hline \multirow[t]{4}{*}{ IT3270017 } & MAR1 & $45^{\circ} 03.584^{\prime} \mathrm{N}$ & $12^{\circ} 21.614^{\prime} \mathrm{E}$ & 1.0 & 66.1 & 22.1 & 11.8 & NO \\
\hline & MAR2 & $45^{\circ} 03.144^{\prime} \mathrm{N}$ & $12^{\circ} 22.659^{\prime} \mathrm{E}$ & 1.4 & 69.0 & 20.5 & 10.5 & NO \\
\hline & CAL1 & $45^{\circ} 04.696^{\prime} \mathrm{N}$ & $12^{\circ} 18.236^{\prime} \mathrm{E}$ & 0.8 & 19.6 & 48.6 & 31.8 & NO \\
\hline & CAL2 & $45^{\circ} 05.835^{\prime} \mathrm{N}$ & $12^{\circ} 18.809^{\prime} \mathrm{E}$ & 0.8 & 21.1 & 54.2 & 24.7 & NO \\
\hline \multirow[t]{2}{*}{ IT3250030 } & VE1 & $45^{\circ} 15.258^{\prime} \mathrm{N}$ & $12^{\circ} 17.566^{\prime} \mathrm{E}$ & 1.0 & 49.6 & 40 & 11 & Zostera marina \\
\hline & VE2 & $45^{\circ} 21.833^{\prime} \mathrm{N}$ & $1217.452^{\prime} \mathrm{E}$ & 1.9 & 61.9 & 38 & 0 & Cymodocea nodosa \\
\hline \multirow[t]{2}{*}{ IT3250031 } & VE3 & $45^{\circ} 30.924^{\prime} \mathrm{N}$ & $12^{\circ} 26.052^{\prime} \mathrm{E}$ & 0.8 & 23.2 & 50 & 26 & NO \\
\hline & VE4 & $45^{\circ} 33.983^{\prime} \mathrm{N}$ & $12^{\circ} 29.956^{\prime} \mathrm{E}$ & 0.8 & 10.2 & 61 & 28 & Ruppia cirrhosa \\
\hline \multirow[t]{3}{*}{ SI3000238 } & STJUZA 1 & $45^{\circ} 31.709^{\prime} \mathrm{N}$ & $13^{\circ} 36.238^{\prime} \mathrm{E}$ & 0.8 & 21.6 & 34.6 & 43.8 & Cymodocea nodosa \\
\hline & STJUZA 2 & $45^{\circ} 31.762^{\prime} \mathrm{N}$ & $13^{\circ} 36.215^{\prime} \mathrm{E}$ & 0.8 & 26.9 & 46.9 & 26.2 & Cymodocea nodosa \\
\hline & STJUZA 3 & $45^{\circ} 31.816^{\prime} \mathrm{N}$ & $13^{\circ} 36.392^{\prime} \mathrm{E}$ & 0.8 & & & & Cymodocea nodosa \\
\hline \multirow[t]{3}{*}{ SI3000240 } & JERKA 1 & $45^{\circ} 29.980^{\prime} \mathrm{N}$ & $13^{\circ} 35.436^{\prime} \mathrm{E}$ & 0.5 & 1.1 & 45.5 & 53.4 & Cymodocea nodosa \\
\hline & JERKA 2 & $45^{\circ} 29.917^{\prime} \mathrm{N}$ & $13^{\circ} 35.565^{\prime} \mathrm{E}$ & 0.5 & 1.2 & 36.1 & 62.7 & Cymodocea nodosa \\
\hline & JERKA 3 & $45^{\circ} 29.780^{\prime} \mathrm{N}$ & $13^{\circ} 36.033^{\prime} \mathrm{E}$ & 0.5 & & & & Cymodocea nodosa \\
\hline \multirow[t]{3}{*}{ SI3000252 } & SKOZA 1 & $45^{\circ} 32.545^{\prime} \mathrm{N}$ & $13^{\circ} 44.616^{\prime} \mathrm{E}$ & 0.5 & & & & $\mathrm{NO}$ \\
\hline & SKOZA 2 & $45^{\circ} 32.703^{\prime} \mathrm{N}$ & $1345.268^{\prime} \mathrm{E}$ & 0.5 & & & & $\mathrm{NO}$ \\
\hline & SKOZA 3 & $45^{\circ} 33.010^{\prime} \mathrm{N}$ & $13^{\circ} 45.157^{\prime} \mathrm{E}$ & 0.5 & & & & $\mathrm{NO}$ \\
\hline
\end{tabular}


samples were sieved through a $0.5-\mathrm{mm}$ stainless steel sieve. Then the plastic debris was visually identified and removed under a dissection microscope (Nikon SMZ45T, magnification 3.35-300×), counted, measured, and classified into three groups (GESAMP, 2019): large microplastics (0.5-5 mm), mesoplastics $(>5-25 \mathrm{~mm})$, and macroplastics $(>25 \mathrm{~mm})$. Plastic debris was also categorized according to shape, i.e., filaments and fragments. Plastic debris in sediment was reported as density (items $\mathrm{kg}^{-1}$ ) per unit of dried sediment.

Fourier transform infrared spectroscopy (FTIR) analysis of plastic debris was carried out with a CARY 600 FT-IR (Agilent Technologies) instrument. Measurements were carried out in attenuated total reflectance (ATR) configuration, with a Pike Miracle diamond cell. Tests were carried out at $25{ }^{\circ} \mathrm{C}$ in dry air. Particles were identified by comparing FT-IR absorbance spectra of the microplastics to those in a polymer reference library. A subsample (about $30 \%$ ) of the collected plastics was analyzed.

All necessary precautions were implemented to minimize microplastic contamination while handling and processing the samples: cotton lab coats and nitrile gloves were worn in the laboratory, and the samples were capped with aluminum foil and glass caps during the identification and analysis to minimize airborne contamination. The fraction of smaller microfibers $(<0.5 \mathrm{~mm})$ is reported as the one that can be overestimated due to environmental contamination (Lusher et al., 2017): in our study we believe that this error may be negligible, as $0.5 \mathrm{~mm}$ was the minimum size of the particles we have considered.

\section{Results}

A total of 42 sediment samples were analyzed from the 21 sites. Granulometric analysis (Folk, 1980) showed sediment consisting of fine sediments, with a texture of silt and clay for the majority of samples, while some samples from IT3270017 and IT3250030 showed sediment composition of sand-silt (Table 1).

All sites except one (VE4 at IT3250031) were found to be polluted by plastics. Plastic particles ranged from 0.5 to $12 \mathrm{~mm}$ in length. The samples contained both filaments and fragments in a range of colors, implying that particles may have originated from multiple sources. In Table 2, the percent amount per SAC of size type and shape type of collected plastics is shown. Considering size, large microplastics $(0.5-5 \mathrm{~mm})$ accounted for the vast majority of the collected plastics, ranging from $100 \%$ at sites VE1, 2 , and 3 (IT3250030 and IT3250031) to 61.6\% at sites JERKA (SI3000240). Considering shape, fragments were more represented than filaments. Fragments are likely derived from the breakdown of larger plastics, while filaments may be derived from the breakdown of synthetic fishing lines, nets, and ropes.

The greatest plastic concentration in terms of counted items (Fig. 2) was recorded at site GOR1 $\left(2250 \pm 420\right.$ items $\mathrm{kg}^{-1}$; IT4060005), while the lowest was at site VE1 $\left(28.4 \pm 40.2\right.$ items $\mathrm{kg}^{-1}$; IT3250030) with the exception of the clear samples recorded at site VE4 (none; IT3250031). As reported in Fig. 2, the variability in plastic concentrations between stations was relatively high, as shown by the quite large values of SD, and the values recorded at different SACs were significantly different from one another. One-way ANOVA
Table 2 Percent amount per SAC of size type and shape type of collected plastics

\begin{tabular}{|c|c|c|c|c|c|c|}
\hline \multirow[t]{3}{*}{ SAC } & \multirow[t]{3}{*}{ Sites } & \multicolumn{3}{|l|}{ Size } & \multicolumn{2}{|l|}{ Shape } \\
\hline & & Micro & Meso & Macro & Filament & Fragment \\
\hline & & $\%$ & $\%$ & $\%$ & $\%$ & $\%$ \\
\hline IT4060005 & GOR & 77.9 & 20.2 & 1.9 & 30.4 & 69.6 \\
\hline IT3270017 & CAL-MAR & 74.9 & 21.8 & 3.3 & 22.4 & 77.6 \\
\hline IT3250030 & VE (1-2) & 100 & 0 & 0 & 1.9 & 98.1 \\
\hline IT3250031 & $\operatorname{VE}(3-4)$ & 100 & 0 & 0 & 4.9 & 95.1 \\
\hline SI3000238 & STJUZA & 69.8 & 16.4 & 13.8 & 35.8 & 64.2 \\
\hline SI3000240 & JERKA & 61.6 & 19.4 & 19.0 & 49.5 & 50.5 \\
\hline SI3000252 & SKOZA & 68.8 & 15.3 & 15.9 & 31.5 & 68.5 \\
\hline
\end{tabular}


Fig. 2 Sediment plastic concentration at the study sites (bars are standard deviation)

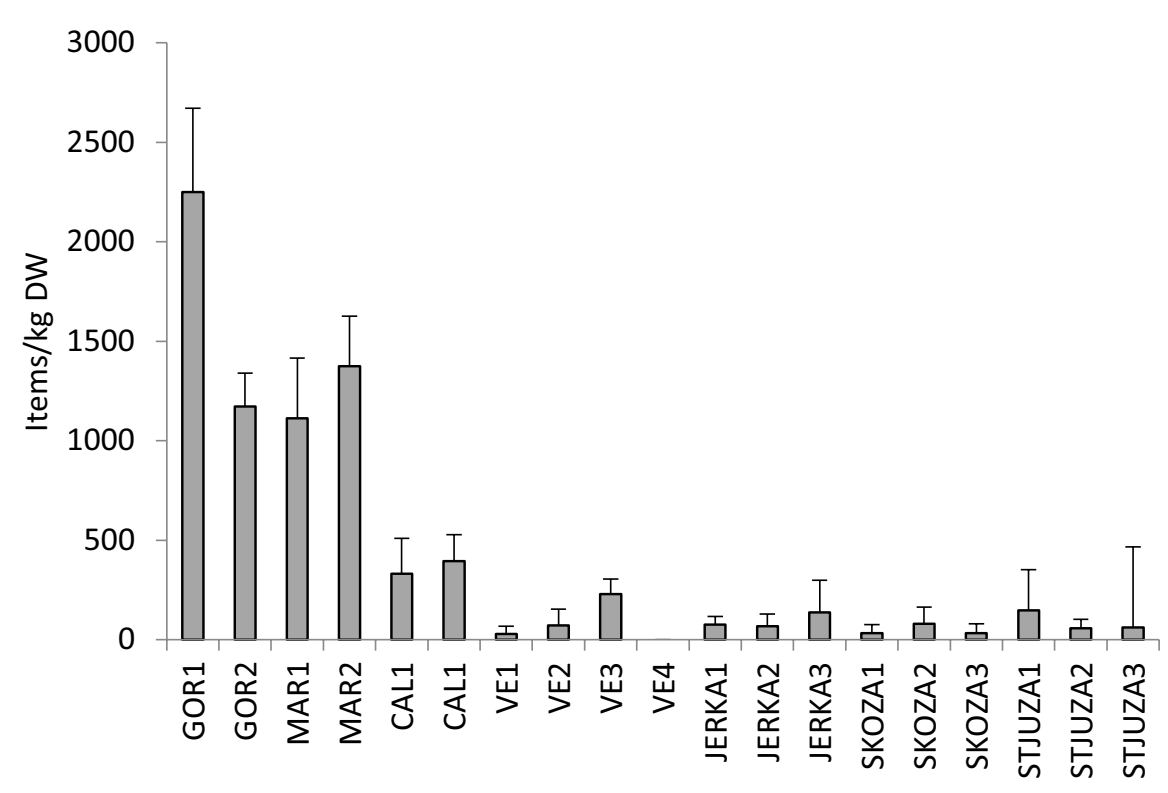

on square root-transformed concentration data (Cochran test; Snedecor \& Cochran, 1968), followed by LSD pairwise comparison tests, showed that there were significant differences in spatial variation of amount of plastic items, with the Po Delta lagoons (IT4060005 and IT3270017, sites GOR, MAR, CAL) showing higher concentrations of plastics (all $p<0.001$ ).

A subset of plastic particles $(n=70)$ collected from 6 SACs (all except SI3000238) was analyzed using FT-IR and compared with reference spectra. Identification through FT-IR spectroscopy showed the presence of 8 polymer types: polyethylene (omo and copolymer, PE), polypropylene (omo and copolymer, PP), polyethylene terephthalate (PET), polyvinyl chloride (PVC), nylon 6.6 (nylon), polysiloxanes (PSX), polystyrene (PS), and thermoplastic polyurethane (TPU), plus some fragments which, due to the high level of degradation, we have not been able to identify. Some examples of plastic particles collected during the study are shown in Fig. 3. The composition by abundance of polymer type is shown in Fig. 4. There were differences in the most common polymers found at different SACs: PET was dominant in the eastern areas $(49.4 \%$ and $36 \%$ at JERKA and SKOZA, respectively), while $\mathrm{PE}$ was dominant in the western areas (50\% at VE; $42.2 \%$ and $43.4 \%$ at GOR and MAR, respectively).

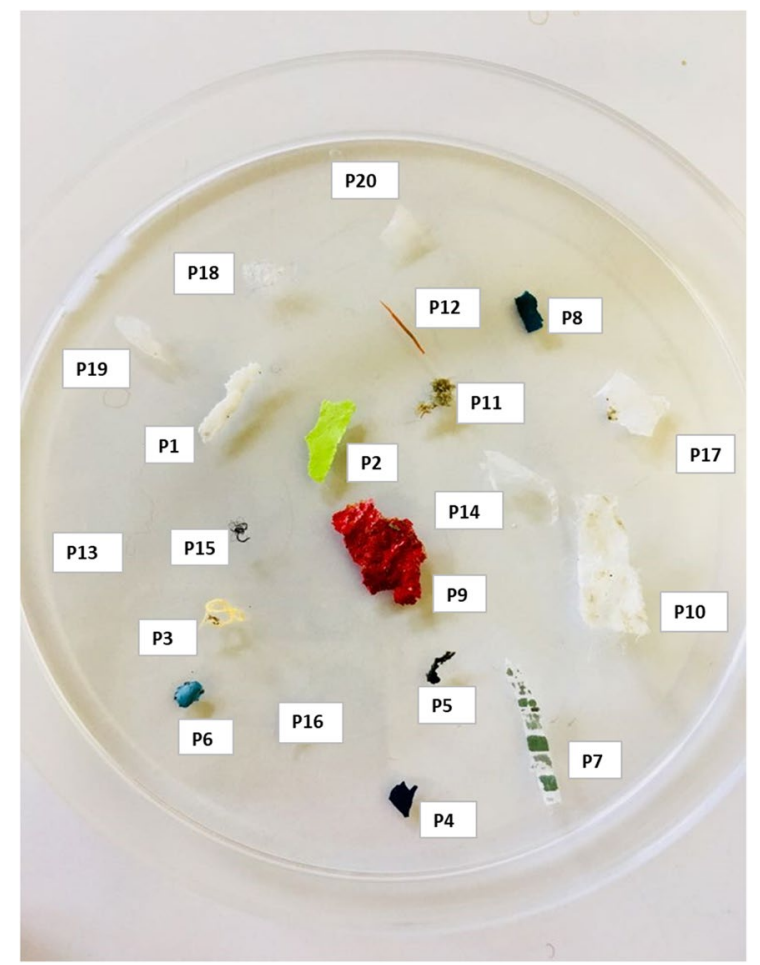

Fig. 3 Examples of plastic particles collected during the study (P1: polysiloxane; P2, P3, and P4: PET; P5: PVC; P6: PET; P7: PE; P8 and P9: PET; P10: PP; P11: nylon-6; P12: PP; P13: unknown; P14: PE; P15: PET; P16: unknown; P17: PE; P18: unknown; P19: polysiloxane; P20: PE) 
Fig. 4 Composition of polymer type at the five analyzed SACs

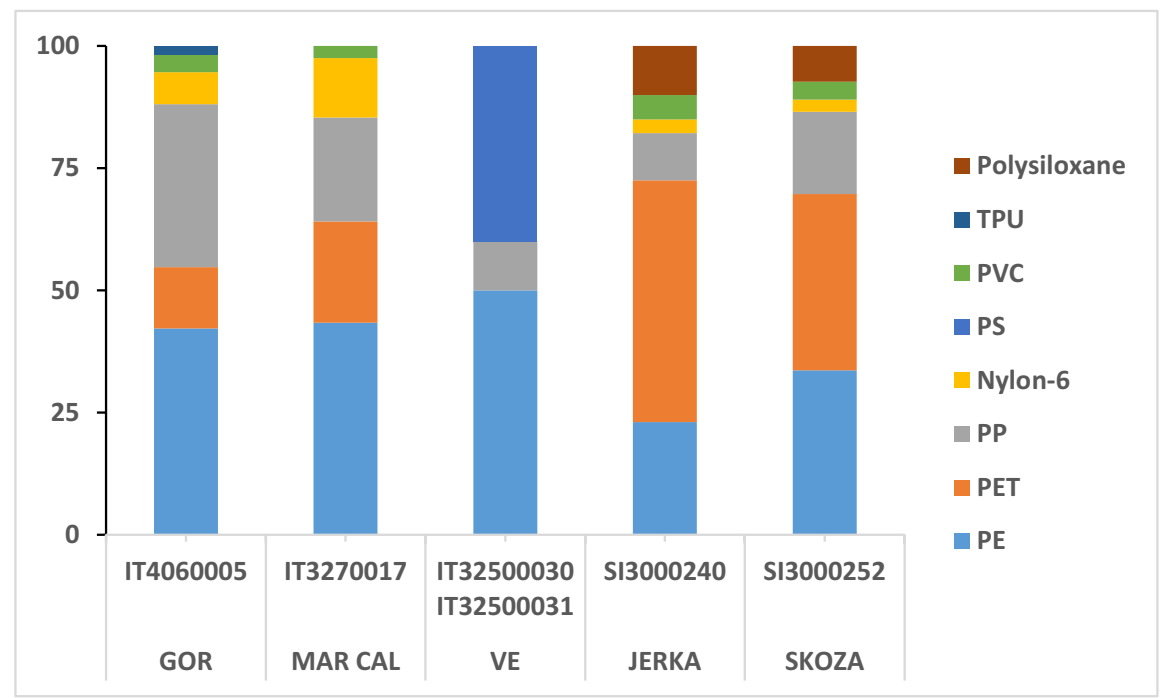

\section{Discussion}

Studies concerning contamination by plastics and microplastics of Mediterranean protected Special Areas of Conservation (SACs) are not numerous. Vianello et al. (2013) extensively studied microplastics in the Venice Lagoon, while Blăsković et al. (2017) studied those in the natural park of Telaščica Bay. We gathered seabed small plastic debris $(>0.5 \mathrm{~mm})$ while sampling benthic invertebrates from 7 SACs in the Gulf of Venice. Because of the high cost involved with sampling the seabed, no historical data are available from SACs in the Gulf of Venice for assessing trends in plastic and microplastic contamination. Despite some limitations, such as the minimum size of plastics collected, this "by-catch study" is the first extensive study to present an assessment of seabed plastic pollution in lagoon and estuarine protected areas of the Gulf of Venice. "By-catch studies" like this one may help to address the gap in knowledge and to make available otherwise unavailable data for future comparisons for instance in the framework of the MSFD implementation (e.g., Ramirez-Llodra et al., 2013).

Differences in plastic concentrations between the different geographic locations considered in this study can be due to: (i) the riverine contribution (Lebreton et al., 2017), in particular of the Po river (Munari et al., 2021), in transporting plastic debris, and (ii) the type of currents and circulation in the Gulf of Venice. In fact, the general surface circulation of the Gulf may be described as a large-scale cyclonic meander, with a northerly flow along the eastern coast and a southerly return flow along the western coast (Orlić et al., 1992). This probably causes the plastic debris carried by rivers to settle preferentially in the environments of the western side of the Gulf: the spatial distribution for plastic contamination seems to follow the conceptual model proposed by Liubartseva et al. (2016) for floating debris in the northern Adriatic Sea.

Sediments of transition environments are subjected to the accumulation of plastics (Table 3). The concentrations we found are in the same range with those studies; however, concerning shape types our results are in contrast with the majority of them, where fibers are the most common shape type of plastics found in sediments. Gago et al. (2018), reviewing published data from 1960 to 2017, found that fibers were found in sediments of almost every marine habitat around the world, in a higher number compared to plastic pellets or fragments, even in the most remote areas (González-Pleiter et al., 2020). However, in their pioneering study on microplastic contamination of the Venice Lagoon, Vianello et al. (2013) found that fragments $(87 \%)$ were more common than filaments $(10 \%)$ on the lagoon seabed. A similar result was found by Gray et al. (2018) in Carolina estuaries.

A hypothesis which could justify the difference of our results from others could be that the method of collection and identification adopted meant that part of the smaller filaments were lost and thus not counted. However, the same method was used by us in 
Table 3 Concentration and most common shape in plastics/microplastics from transition environments

*items $\mathrm{m}^{-2}$

\begin{tabular}{lll}
\hline Transition environment & $\begin{array}{l}\text { Sediment Dominant shape Reference } \\
\text { concentration } \\
\left(\text { items } \mathrm{kg}^{-1}\right)\end{array}$ \\
\hline
\end{tabular}

\begin{tabular}{llll}
\hline Gulf of Venice (Italy-Slovenia) & $28-2250$ & Fragments & This study \\
Guanabara Bay (Brazil) & $160-1000$ & Fibers & Alves and Figuereido (2019) \\
Jagir Estuary (Indonesia) & $92-590$ & Fibers & Firdaus et al. (2020) \\
Tampa Bay (USA) & $30-790$ & Fibers & McEachern et al. (2019) \\
Rías Baixas (Spain) & $70.2 \pm 74.2$ & Fibers & Carretero et al. (2021) \\
Venice Lagoon (Italy) & $672-2175$ & Fragments & Vianello et al. (2013) \\
Charleston Harbor (USA) & $0-2524^{*}$ & Fragments & Gray et al. (2018) \\
Winyah Bay (USA) & $0-796^{*}$ & Fragments & Gray et al. (2018) \\
\hline
\end{tabular}

other studies in marine environments (central Adriatic: Mistri et al., 2017; Ross Sea: Munari et al., 2017a, b; Pianosa island: Mistri et al., 2018; northern Tyrrhenian: Mistri et al., 2020), and in all those studies we found that the filaments and fibers were significantly more numerous than the fragments. All those studies were carried out on much deeper seabeds (30-120 m depth), differently from the bottoms considered in this study, whose depth was lower (0.5-2 m depth). Harris (2020) analyzed the information reported in 80 papers about different marine environments and reported higher fiber contents for the following: beach (median value 90\%), deep sea environments (median value $75 \%$ ), tide-dominated shelf (median value 63\%), and shallow coastal environments $(61 \%)$. The lowest median values for fibers were reported in tide-dominated estuarine systems (median value 49\%), like those examined in this case study. The comparison with other studies, however, is very difficult because the analytical techniques are often very different.

The majority of the polymers identified along the Italian west coast were low-density polymers such as PE, PP, PS, and TPU (which globally composed $64-76 \%$ of the polymers) that are expected to float and travel for longer distances before sinking because of fouling or ingestion by marine organisms (Fazey and Ryan, 2016; Harris, 2020). Conversely PET is expected to sink quickly because of its high density (higher than the average seawater density of $1.03 \mathrm{~g} \mathrm{~cm}^{-3}$ ) and presented higher percentages along the Slovenian coast highlighting the possible role of the cyclonic water circulation of the northern Adriatic Sea on distribution and composition of plastics along the coasts. PS was found in large quantities at VE sites, confirming the observations of Vianello et al.
(2013) about the extensive contamination caused by fragments of this polymer on the seabed of the Venice Lagoon.

The types of polymers found cover virtually any use, and it is therefore extremely difficult to understand where they come from, probably deriving from both land- and sea-based sources. PE, PP, and PET are mainly used for packaging for food (plastic bags, plastic films, containers including bottles), textiles, and stationery; PE, PP, and nylon are used to produce bags and ropes, which are widely used in the local aquaculture and fishing industry; PS is used for producing disposable plastic cutlery and dinnerware; TPU has applications which include sporting goods, footwear, inflatable rafts, and, more recently, in 3D printing; and polysiloxanes are used in many products: electrical (insulation), electronics (coatings), household (cooking utensils), automobile (gaskets), toys, bracelets, personal care (skin and haircare), and even many others.

The seabed is a sink for plastics (Woodall et al., 2014), but, due to its depth, it remains a limited area of study compared to surface water. There are very few studies dealing with plastic contamination of Mediterranean seabed (Llorca et al., 2020), due to the greater technical difficulties in sampling, and the scarcity of resources allocated for these tasks. After that of Vianello et al. (2013), this is the first study evaluating the contamination by plastics and microplastics of the seabed of protected SACs in the Gulf of Venice. We found small plastic particles in almost all the sediment samples collected in transition areas of the Gulf, where plastic contamination appeared to be almost ubiquitous, although the concentration of plastic particles differed among sites. Much higher plastic 
concentration was found at sites on the western side of the Gulf, highlighting the primary role that large rivers (all on the western side of the Gulf), together with the particular type of circulation of the northern Adriatic, play in conveying this type of pollutant.

\section{Conclusions}

This study demonstrates that plastic particles are widely dispersed and abundant in sediments of protected transition areas in the Gulf of Venice, but in higher quantities on the seabed of the western side SACs. As SACs like those considered in this study provide feeding, reproductive, and wintering ground for fish, migratory birds, and living areas for many species with great economic value (e.g., clams, mussels), the accumulation of plastics could pose a threat to the biota and ultimately to human health.

Acknowledgements The authors wish to thank an anonymous reviewer for the valuable suggestions that have helped to improve the paper.

Funding Open access funding provided by Università degli Studi di Ferrara within the CRUI-CARE Agreement.

Data Availability The datasets generated and/or analyzed during the current study are available from the corresponding author on reasonable request.

Open Access This article is licensed under a Creative Commons Attribution 4.0 International License, which permits use, sharing, adaptation, distribution and reproduction in any medium or format, as long as you give appropriate credit to the original author(s) and the source, provide a link to the Creative Commons licence, and indicate if changes were made. The images or other third party material in this article are included in the article's Creative Commons licence, unless indicated otherwise in a credit line to the material. If material is not included in the article's Creative Commons licence and your intended use is not permitted by statutory regulation or exceeds the permitted use, you will need to obtain permission directly from the copyright holder. To view a copy of this licence, visit http://creativecommons.org/licenses/by/4.0/.

\section{References}

Alves, V. E. N., \& Figuereido, G. M. (2019). Microplastic in the sediments of a highly eutrophic tropical estuary. Marine Pollution Bulletin, 146, 326-335. https://doi.org/10.1016/j. marpolbul.2019.06.042.
Bergmann, M., Gutow, L., \& Klages, M. (2015). Marine anthropogenic litter. Springer.

Blăsković, A., Fastelli, P., Čižmek, H., Guerranti, C., \& Renzi, M. (2017). Plastic litter in sediments from the Croatian marine protected area of the natural park of Telaščica bay (Adriatic Sea). Marine Pollution Bulletin, 114, 583-586. https://doi.org/10.1016/j.marpolbul.2016.09.018.

Carretero, O., Gago, J., \& Viñas, L. (2021). From the coast to the shelf: Microplastics in Rías Baixas and Miño River shelf sediments (NW Spain). Marine Pollution Bulletin, 162, 111814. https://doi.org/10.1016/j.marpolbul.2020.111814.

Cózar, A., Sanz-Martìn, M., Martì, E., González-Gordillo, J. I., Ubeda, B., Gálvez, J. Á., Irigoien, X., \& Duarte, C. M. (2015). Plastic accumulation in the Mediterranean Sea. PLoS One, 10, e0121762.

Fazey, F. M. C., \& Ryan, P. G. (2016). Biofouling on buoyant marine plastics: An experimental study into the effect of size on surface longevity. Environmental Pollution, 210, 354-360. https://doi.org/10.1016/j.envpol.2016.01.026.

Firdaus, M., Trihadiningrum, Y., \& Lestari, P. (2020). Microplastic pollution in the sediment of Jagir Estuary, Surabaya City, Indonesia. Marine Pollution Bulletin, 150, 110790. https://doi.org/10.1016/j.marpolbul.2019. 110790.

Folk, R. L. (1980). Petrology and sedimentary rocks (2nd ed., p. 184p). Hemphill Press.

Gago, J., Henry, M., \& Galgani, F. (2015). First observation on neustonic plastics in waters off NW Spain (spring 2013 and 2014). Marine Environmental Research, 111, 27-33. https://doi.org/10.1016/j.marenvres.2015.07.009.

Gago, J., Carretero, O., Filgueiras, A. V., \& Viñas, L. (2018). Synthetic microfibers in the marine environment: A review on their occurrence in seawater and sediments. Marine Pollution Bulletin, 127, 365-376. https://doi.org/10.1016/j. marpolbul.2017.11.070.

GESAMP, 2019. Guidelines on the monitoring and assessment of plastic litter and microplastics in the ocean. Kershaw P.J., Turra A. and Galgani F. Editors. (IMO/FAO/ UNESCO-IOC/UNIDO/WMO/IAEA/UN/UNEP/UNDP/ ISA Joint Group of Experts on the Scientific Aspects of Marine Environmental Protection). Rep. Stud. GESAMP No. 99, 130p.

González-Pleiter, M., Velázquez, D., Edo, C., Carretero, O., Gago, J., Barón-Sola, A., Hernández, L. E., Yousef, I., Quesada, A., Leganés, F., Rosal, R., \& Fernández-Piñas, F. (2020). Fibers spreading worldwide: Microplastics and other anthropogenic litter in an Arctic freshwater lake. Science of the Total Environment, 722, 137904. https:// doi.org/10.1016/j.scitotenv.2020.137904.

Gray, A. D., Wertz, H., Leads, R. R., \& Weinstain, J. E. (2018). Microplastic in two South Carolina Estuaries: Occurrence, distribution, and composition. Marine Pollution Bulletin, 128, 223-233. https://doi.org/10.1016/j. marpolbul.2018.01.030.

Harris, P. T. (2020). The fate of microplastic in marine sedimentary environments: A review and synthesis. Marine Pollution Bulletin, 158, 111398. https://doi.org/10.1016/j. marpolbul.2020.111398.

Jambeck, J. R., Geyer, R., Wilcox, C., Siegler, T. R., Perryman, M., Andrady, A., Narayan, R., \& Lavender Law, K. 
(2015). Plastic waste input from land into ocean. Science, 347, 768-771. https://doi.org/10.1126/science.1260352.

Laglbauer, B. J. L., Melo Franco-Santos, R., Andreu-Cazenave, M., Brunelli, L., Papadatou, M., Palatinus, A., Grego, M., \& Deprez, T. (2014). Macrodebris and microplastics from beaches in Slovenia. Marine Pollution Bulletin, 89, 356-366. https://doi.org/10.1016/j.marpolbul. 2014.09.036.

Lebreton, L., van der Zwet, J., Damsteeg, J. W., Slat, B., Andrady, A., \& Reisser, J. (2017). River plastic emissions to the world's oceans. Nature Communication, 8, 15611. https://doi.org/10.1038/ncomms15611.

Liubartseva, S., Coppini, G., Lecci, R., \& Creti, S. (2016). Regional approach to modeling the transport of floating plastic debris in the Adriatic Sea. Marine Pollution Bulletin, 103, 115-127. https://doi.org/10.1016/j.marpolbul. 2015.12.031.

Llorca, M., Álvarez-Muñoz, D., Ábalos, M., RodríguezMozaz, S., Santos, L. H. M. L. M., León, V. M., Campillo, J. A., Martínez-Gómez, C., Abad, E., \& Farré, M. (2020). Microplastics in Mediterranean coastal area: Toxicity and impact for the environment and human health. Trends in Environmental Analytical Chemistry, 27, e00090. https://doi.org/10.1016/j.teac.2020.e00090.

Lubchenco, J., \& Grorud-Colvert, K. (2015). Making waves: The science and politics of ocean protection. Science, 350, 22-23. https://doi.org/10.1126/science.aad5443.

Lusher, A. L., Welden, N. A., Sobral, P., \& Cole, M. (2017). Sampling, isolating and identifying microplastics ingested by fish and invertebrates. Analytical Methods, 9, 1346-1360. https://doi.org/10.1039/C6AY02415G.

Marine Strategy Framework Directive (2008). Directive 2008/56/EC of the European Parliament and of the Council of 17 June 2008 establishing a framework for community action in the field of marine environmental policy.

McEachern, K., Alegria, H., Kalagher, A. L., Hansen, C., Morrison, S., \& Hastings, D. (2019). Microplastics in Tampa Bay, Florida: Abundance and variability in estuarine waters and sediments. Marine Pollution Bulletin, 148, 97-106. https://doi.org/10.1016/j.marpolbul.2019.07.068.

Mistri, M., Infantini, I., Scoponi, M., Granata, T., Moruzzi, L., Massara, F., De Donati, M., \& Munari, C. (2017). Small plastic debris in sediments from the Central Adriatic Sea: Types, occurrence and distribution. Marine Pollution Bulletin, 124, 435-440. https://doi.org/10.1016/j.marpo lbul.2017.07.063.

Mistri, M., Infantini, I., Scoponi, M., Granata, T., Moruzzi, L., Massara, F., De Donati, M., \& Munari, C. (2018). Microplastics in marine sediments in the area of Pianosa Island (Central Adriatic Sea). Rendiconti Lincei, 29, 805-809. https://doi.org/10.1007/s12210-018-0736-1.

Mistri, M., Scoponi, M., Granata, T., Moruzzi, L., Massara, F., \& Munari, C. (2020). Types, occurrence and distribution of microplastics in sediments from the northern Tyrrhenian Sea. Marine Pollution Bulletin, 153, 111016. https:// doi.org/10.1016/j.marpolbul.2020.111016.

Munari, C., Corbau, C., Simeoni, U., \& Mistri, M. (2016). Marine litter on Mediterranean shores: Analysis of composition, spatial distribution and sources in northwestern Adriatic beaches. Waste Management, 49, 483-490. https://doi.org/10.1016/j.wasman.2015.12.010.
Munari, C., Infantini, I., Scoponi, M., Rastelli, E., Corinaldesi, C., \& Mistri, M. (2017a). Microplastics in the sediments of Terra Nova Bay (Ross Sea, Antarctica). Marine Pollution Bulletin, 122, 161-165. https://doi.org/10.1016/j. marpolbul.2017.06.039.

Munari, C., Scoponi, M., \& Mistri, M. (2017b). Plastic debris in the Mediterranean Sea: Types, occurrence and distribution along Adriatic shorelines. Waste Management, 67, 385391. https://doi.org/10.1016/j.wasman.2017.05.020.

Munari, C., Scoponi, M., Sfriso, A.A., Sfriso, A., Ajello, J., Casoni, E., Mistri, M. (2021). Temporal variation of floatable plastic particles in the largest Italian river, the Po. Marine Pollution Bulletin, in press.

Orlić, M., Gačić, M., \& La Violette, P. E. (1992). The currents and circulation of the Adriatic Sea. Oceanologica Acta, 15, 109-124.

Pasquini, G., Ronchi, F., Strafella, P., Scarcella, G., \& Fortibuoni, T. (2016). Seabed litter composition, distribution and sources in the Northern and Central Adriatic Sea (Mediterranean). Waste Management, 58, 41-51. https://doi.org/ 10.1016/j.wasman.2016.08.038.

PlasticsEurope. (2018). Plastics - The facts 2018: An analysis of European plastics production, demand and waste data. Brusseles.

Ramirez-Llodra, E., De Mol, B., Company, J. B., Coll, M., \& Sardà, F. (2013). Effects of natural and anthropogenic processes in the distribution of marine litter in the deep Mediterranean Sea. Progress in Oceanography, 118, 273-287. https://doi.org/10.1016/j.pocean.2013.07.027.

Snedecor, G. W., \& Cochran, W. G. (1968). Statistical methods (p. 593). Iowa State university Press.

Strafella, P., Fabi, G., Spagnolo, A., Grati, F., Polidori, P., Punzo, E., Fortibuoni, T., Marceta, B., Raicevich, S., Cvitkovic, I., Despalatovic, M., \& Scarcella, G. (2015). Spatial pattern and weight of seabed marine litter in the northern and central Adriatic Sea. Marine Pollution Bulletin, 91, 120-127. https://doi.org/10.1016/j.marpolbul.2014.12.018.

UNEP (2018). Single use plastics: A road to sustainability. Nairobi: UNEP, $92 \mathrm{pp}$.

UNEP/MAP/MEDPOL, 2009. Results of the assessment of the status of marine litter in the Mediterranean. In: Meeting of MED POL focal points no. 334, 91 pp.

Vethaak, A. D., \& Leslie, H. A. (2016). Plastic debris is a human health issue. Environmental Science Technology, 50, 68256826. https://doi.org/10.1021/acs.est.6b02569.

Vianello, A., Boldrin, A., Guerriero, P., Moschino, V., Rella, R., \& Sturaro, a., Da Ros, L., . (2013). Microplastic particles in sediments of Lagoon of Venice, Italy: First observations on occurrence, spatial patterns and identification. Estuarine Coastal Shelf Science, 130, 54-61.

Woodall, L.C., Sanchez-Vidal, A., Canals, M., Paterson, G.L.J., Coppock, R., Sleight, V., Calafat, A., Rogers, A.D., Narayanaswamy, B.E., Thompson, R.C. (2014). The deep sea is a major sink for microplastic debris. Royal Society Open Sciences 1. https://doi.org/10.1098/rsos.140317.

Publisher's Note Springer Nature remains neutral with regard to jurisdictional claims in published maps and institutional affiliations. 